\title{
Rethinking water and crops management in the irrigated district of Diyar-Al-Hujjej (Tunisia)
}

Issam Daghari ( $\sim$ issam.daghari@gmail.com )

Institut National Agronomique de Tunis

Fatma Bader Abouaziza

University of Tripoli

Hedi Daghari

Institut National Agronomique de Tunis

\section{Research Article}

Keywords: Seawater intrusion, salinization spreading, water blending, famer's practices, crops choice, salt brought, net revenue

Posted Date: April 15th, 2021

DOI: https://doi.org/10.21203/rs.3.rs-320835/v1

License: (1) This work is licensed under a Creative Commons Attribution 4.0 International License. Read Full License

Version of Record: A version of this preprint was published at Environmental Science and Pollution Research on July 10th, 2021. See the published version at https://doi.org/10.1007/s11356-021-15155-z. 


\section{Abstract}

In Diyar-Al-Hujjej irrigated area, aquifer's over-exploitation, sea intrusion and abandonment of irrigated areas and wells were took place. A yield decrease for all crops was observed. Average aquifer water electrical conductivity (EC) jumps from 4 $\mathrm{dS} / \mathrm{m}$ to $6.6 \mathrm{dS} / \mathrm{m}$ between 1969 and 2017. A fresh surface water transfer over more than $100 \mathrm{~km}$ was launched in 1998 to safeguard this irrigated area but this fresh water supply is not stable, it varies from one year to another (about 1,900,000 $\mathrm{m}^{3}$ in 2015 and only $60,000 \mathrm{~m}^{3}$ in 2018) while annual cops water requirements of the perimeter is about 2,500,000 $\mathrm{m}^{3}$. An adaptation by farmers to this new situation of saline and water stress was observed. The follow-up surveys of the farmer's practices showed that: (i) new crops with high added-value grown during the rainy season were introduced in association with dry season crops (strawberry-pepper association), (ii) rainfed crops, fallow and water blending are common practices, and (iii) growing of rainy season crops in the aim to reduce water supply. The instability of fresh surface water volume transferred constitutes the main threat for this perimeter. The use of aquifer salt water must be stopped; it is the cause of the large quantities of salts supplied (over $13,000 \mathrm{~kg} / \mathrm{ha}$ ) and also of the low annual net income achieved. Net revenue was less than 2,000 US \$/ha under salt water and reached even 8,000 US $\$ /$ ha when sufficient surface water is available. An agrarian reform policy must be applied for this perimeter; only crops whose water requirements are partially met by rain should be grown. Introduction of another more sustainable water source should be initiated (as desalination) even at private farm level.

\section{Introduction}

The advanced degradation, limits and vulnerability of all natural resources are unanimous all over the world and especially in regions where high population density and intense economic activities are present. Competition between the different users of these resources is often observed. In Tunisia, good quality water is reserved for drinking water and in case of water shortage; irrigated areas receive quantities of water lower than their actual needs (even no supply sometimes for vegetable crops). In our irrigated area, fresh surface water supply was about 1,900,000 and 60,000 $\mathrm{m}^{3}$ during respectively2015 and 2018.

According to the FAO, 7.3 million hectares salted are located in Spain, Morocco, Tunisia and Turkey for a total of 27.3 million hectares for the entire Mediterranean region (Aragüés et al., 2011). Coastal aquifers around the Mediterranean and more particularly in North Africa are increasingly degraded and over-exploited. In Tunisia, salty soils occupy 1.5 million hectares ( $25 \%$ of the total area of cultivable soils (Hamrouni and Daghari 2010$)$ ). Agriculture will remain a key sector; it accounts for more than $11 \%$ of the gross domestic product and provides employment for more than $20 \%$ of the working population. The irrigated sector contributes to more than $35 \%$ of national agricultural production. Unfortunately, Tunisia is a country with very limited water resources. The quota of a Tunisian does not exceed $500 \mathrm{~m}^{3}$ per inhabitant per year. A third of Tunisia's mobilizable water resources have salinity greater than $4.5 \mathrm{dS} / \mathrm{m}$. Also, $50 \%$ of the sampled wells in Northern Tunisia have salinity higher than 3dS/m (Söderströmet al.1992). Furthermore, all regions of Tunisia suffer from high groundwater salinity; this is the case of our irrigated area and a lot of other regions such as all the south when average rain is about only $100 \mathrm{~mm}$. Crops yield is very low due to salinity; in Tunisian oases, driving force of development for all of southern Tunisia, the average yield of irrigated date palms is 4.6 tons/ha while it's 41 tons/ha (9 times) in Egypt (El-Juhany 2010; Zafar 2020).

In the region of Diyar-Al-Hujjej, site of our study, aquifer over-exploitation combined with the rain's irregularity led to a drop in the water table level, sea intrusion and yields decline. A low tomato yield (less than 20 tons/ha) has been observed. Wells (EC) of more than $30 \mathrm{dS} / \mathrm{m}$ and depressions from sea level down to $-13 \mathrm{~m}$ were measured (Chekirbane et al. 2014).

These highs (EC) have led to the abandonment of wells and farms and the migration of farmers to other areas less affected by salinity, often in the form of tenants. The average sodium adsorption ratio (SAR) was $8.6^{0.5}$ (meq L-1) and the average electrical conductivity (EC) was $6.6 \mathrm{dS} / \mathrm{m}$, (Mekni 2017). The number of abandoned wells increased from 1,268 to 3,200 between 1980and 2005 in Diyar-Al-Hujjej and surrounding areas (Cap Bon peninsula). 
As emergency measures, there was recourse to the transfer of surface fresh water from another geographical region (northwest) of Tunisia, via the Cap Bon Medjerda canal over approximately $100 \mathrm{~km}$ with several pumping stations. This operation of water transfer is highly contested last years by the population living in the watershed from which the water transfer is made. On another side, feasibility of using seawater desalination shows its limit; besides environmental problems but renewable and clean energy usage can help sustain environmental conditions in the opposite of fossil fuel-based energy (Abbes et al. 2020). Desalinated water cost is very high (more than $0.5 \mathrm{US} \$ / \mathrm{m}^{3}$ ) while the selling price of surface water is $0.05 \mathrm{US} \$ / \mathrm{m}^{3}$ and the cost of pumped saline water is only $0.02 \mathrm{US} \$ / \mathrm{m}^{3}$. The salt seawater desalination analysis showed clearly, that the application of desalinated seawater in the current situation leads to a negative net marginal value except for crops with high added-value (strawberry), (Daghari et al. 2020a). But no agro-industry exists for strawberries; the market is very limited and it is a crop that spoils in two or three days. As desalination is beyond the reach of farmers today, it was deemed more appropriate to analyze the farmer's practices.

In the irrigated area of Dyiar-Al-Hujjej, all farmers are aware of the salinity problem. Some new practices were adopted in the aim to manage salt, water and crops over time:

- water blending and over-irrigation with fresh water in the aim to drop soil salinity

- introduction of new and more profitable crops such as strawberry following this supply of fresh water and the practice of associated crops on the same site (strawberry-pepper combination), (Daghari et al. 2020b).

- growing of winter and spring crops in the aim to reduce water supply,

- adoption of crops rotation by the application of successions between irrigated crops, rainfed crops and fallow by all farmers in order to reduce soil salinity even if the farms size is very low; farms with an area of less than 4 ha represent $60 \%$.

It is only recently that the behaviour of farmers and their perception of salinity have started to be studied. There is no clear agreement on what constitutes best practices for managing salinity in this region especially since the fresh surface water volume is very irregular (Table 1). Considering the heaviness of these experiments, only modeling was often used (Lahlou et al. 2000; Kaur et al. 2007; Arafat 2019) but field studies are lacking. Some studies were carried out over short periods and only looked at salinity (Daghari et al. 2020b), (Azza et al. 2020). Total amounts of salt brought, farmer's net revenue and salinity evolution for a long period (many years) were not studied before. The objective of this paper is to compare farmers' practices in an irrigated area whose irrigation water comes from a saline aquifer and very irregular transferred surface fresh water but certain prosperity is observed in this perimeter despite water and salt stress.

\section{Materials And Methods}

\section{Study area}

Dyiar-Al-Hujjej located in the Cap Bon peninsula of Tunisia (Figure 1) having as coordinates $36^{\circ} 35^{\prime}$ North and $10^{\circ} 52^{\prime}$ East.The average potential evapotranspiration and annual rainfall were respectively $1,166 \mathrm{~mm}$ and $441 \mathrm{~mm}$ for the period (1968 - 2020). Dyiar-Al-Hujjej's aquifer (EC) was $6.6 \mathrm{dS} / \mathrm{m}$ in 2017, wells depth is about $20 \mathrm{~m}$ measured in 2011, 2017 and 2020 and it's the main region when strawberry is grown (more than 95\%). Only localized irrigation is encountered and irrigation uniformity is about $90 \%$ (Daghari et al. 2020b).

Meetings with extension services, farmers and farmers' association called "izdihar" were carried out. The crops predominantly grown are vegetable crops (pepper, potato, strawberry, squash, tomato....). Soil profiles showed that the crust is often present from $20 \mathrm{~cm}$ depth sometimes; after granular analysis, percentages of clay, silt and sand were respectively $9 \%, 36 \%$ and $55 \%$. Crops choice varies depending on available water sources. Thanks to the availability of surface water from the state network supply, the growth of a high added-value crop which is strawberry is increasing every year. Its agricultural production value is about 15,600 US $\$$ /ha while it's less than 3,000 US $\$ /$ ha for all other crops. This 
explains the increase in the area occupied by strawberries from zero hectares in 1999, 55 ha in 2000 to 150 ha in 2011 and 121 ha in 2019. Cost production of strawberry is very high ( $0.2 \mathrm{USD} /$ plant) and it isn't within the reach of all farmers; it's about 6,000 US $\$ /$ ha while it's less than 2,000 US $\$ /$ ha for all other crops. The cultivated areas dedicated to tomato which is a summer crop with high water requirement, decreased from 450 ha in 2000 to only 70 ha in 2019 . The farms size is divided into two classes 0-4 ha and 4-10 ha, each occupying 435 ha with 185 farmers and 365 ha with 60 farmers, respectively.

The farmers were grouped according to three different scenarios: (i) farmers who use only fresh surface water from the state network, (ii) farmers who blend surface water and saline groundwater resulting in decreased water salinity, and (iii) farmers who use only saline groundwater. Each group has its own strategy regarding crops grown and crops rotation. (EC) measured on December $2^{\text {th }}, 2020$ were 2.4 and $4.4 \mathrm{dS} / \mathrm{m}$ respectively for fresh surface water and aquifer saline water. These values were respectively 2.82 and $4.36 \mathrm{dS} / \mathrm{m}$ on February $26^{\text {th }} 2021$.

\section{Experiments}

(EC) was measured using the method of saturated paste extract and Geonics conductivemeter (EM 38); irrigation water amounts supplied were tracked by water-meter monthly. Also, wells (EC) and depths were measured by using conductivimeter, and piezometric probe respectively. For different crops rotations encountered, (EC) were measured during September 2017-February 2021. The last salinities measurements were carried out on December 2, 2020 and on February 2021 over an area after three important rains of about $30 \mathrm{~mm}$ each. During the years 2016, 2017, 2018, 2019 and 2020 , the volume of surface fresh water supplied is very low and many areas were not occupied by irrigated crops. During 2019, the volume of surface water pumped was 780,389 while the volume distributed was only 620,000 , a loss rate of $21 \%$; the number of hydrants used was 138 for a total of 266 with a rate of $52 \%$.

\section{Main equations}

\section{- Relative yield}

Relative yield $\left(Y_{r}\right)$ is calculated by using the following equation (Maas and Hoffman 1977):

$Y_{r}=100-b\left(E C_{s}-a\right)$

where $b=$ the curve slope expressed in percent per $\mathrm{dS} / \mathrm{m}$ (equal to $14,12,10.5,33$ and 9.9 respectively for pepper, potato, squash, strawberry and tomato), a = the salinity threshold expressed in $\mathrm{dS} / \mathrm{m}$ (equal to 1.5, 1.7, 4.9, 1 and 2.5 respectively for pepper, potato, squash, strawberry and tomato).

$\mathrm{EC}_{\mathrm{S}}=$ the mean electrical conductivity of a saturated paste, measured in the root zone $(\mathrm{dS} / \mathrm{m})$

\section{- Salt brought}

The quantities of salt brought $\left(Q_{s}\right)$ are calculated using this equation:

$Q_{s}=$ Volume of water $(V)$ * water salinity $(S) \quad(2)$

with $\mathrm{Q}_{\mathrm{s}}(\mathrm{kg} / \mathrm{ha}), \mathrm{V}\left(\mathrm{m}^{3} / \mathrm{ha}\right)$ and $\mathrm{S}(\mathrm{g} / \mathrm{l})=$ water electrical conductivity $(\mathrm{EC}) \star 0.64$

\section{- Net revenue N:}

$\mathrm{N}=$ value of agricultural products (US \$/ha) - (production cost (US \$/ ha) + water cost (US \$/ ha)) (3)

with production costs (US \$/ha),(= product selling price (US \$/kg) * yield (kg/ha)) and water cost (US \$/ ha), (= volume of water $\left(\mathrm{m}^{3}\right)$ *selling price of water cubic meter (US $\left.\$ / \mathrm{m}^{3}\right)$ ). 
Selling prices at farm level of agricultural products, water prices or costs, production cost, crops yield considered are taken according to the Tunisian Ministry of Agriculture, Water Resources and Fisheriesdatabase.

\section{Results And Discussion}

In our irrigated area, crops grown and crops rotation depend mainly on available water sources; surface water is available on uncertain amounts. The volume of surface water transferred is irregular and varies from year to another $(1,929,322$ and $60,503 \mathrm{~m}^{3}$ respectively for the years 2015 and 2018 ) depending on the water volume stored in dams (Table 1 ). Average net crops water requirements calculated by the CROPWAT model, (Allen et al. 1998) are about 2,500,000 $\mathrm{m}^{3}$ for this irrigated area. Tunisia is going through a dry period since 2016; the water stored volume in dams in Tunisia is less than $50 \%$ of their capacity; priority is given to potable water. Irrigated areas are very restricted during 2016, 2017, 2018 and 2019.

Table 1. Fresh surface water volume supplied to the irrigated area of Diyar-Al-Hujjej (Tunisia) (GDA (farmer's association, 2021)

\begin{tabular}{|llllllllll|}
\hline Year & 2000 & 2010 & 2011 & 2015 & 2016 & 2017 & 2018 & 2019 & 2020 \\
\hline $\begin{array}{l}\text { Supplied } \\
\text { water } \\
\text { volume } \\
\left(\mathrm{m}^{3}\right)\end{array}$ & $1,569,467$ & $1,714,603$ & $1,714,421$ & $1,929,322$ & 878,324 & 302,382 & 60,503 & 620,000 & 920,000 \\
\hline
\end{tabular}

During the dry seasons April 2000-August 2000, April 2012-August 2012 and April 2019-August 2019, the volume of surface water supplied were respectively $1,085,510 ; 1,225,675$ and $306,775 \mathrm{~m}^{3}$ while the average crops water requirement is about $2,408,110 \mathrm{~m}^{3}$. The availability of fresh surface water is the determining factor for cropping choices in this irrigated area.

In the irrigated area of Diyar-Al-Hujjej, for the year 2019, the number of irrigators was 150 with an area of 276 ha (about $39 \%$ of the total equipped area). The volume of water distributed in 2019 was $620,000 \mathrm{~m}^{3}$ while the expected volume is $1,225,000$ $\mathrm{m}^{3}$ (about 200\%). Even in 2020, fresh water supplied still low $\left(920,000 \mathrm{~m}^{3}\right)$ and represent about $50 \%$ of the volumes supplied before 2015 (Table 1).

\section{Farmers having only fresh surface water}

These farmers are often tenants who do not invest in the drilling of wells and the built of tanks necessary for water blending. They grow only crops with high added-value; no rainfed-crops. Soil profiles (EC) measured was about $2 \mathrm{dS} / \mathrm{m}$ for the first year (1.6 under strawberry in May 2018 and 2.2 dS/m under pepper in August 2018), (line 4, Table 2), This relatively low salinity measured is the result of the use of good quality surface water and the leaching of salts under the effect of rain, especially since it is a light soil. Exceptional winter rains of $260 \mathrm{~mm}$ allowed the evacuation of more than $60 \%$ of the initial salt stock (Belouazi, 2010). The combination strawberry-pepper is maintained during a second year especially in September 2018, more than $200 \mathrm{~mm}$ have fallen, which further promotes salts leaching.

The (EC) measured at the end of the second year was $3.2 \mathrm{dS} / \mathrm{m}$ (line 4, Table 2) (Fig. 2, blue curve); so high for strawberry. For an (EC) of $3.2 \mathrm{dS} / \mathrm{m}$, no yield can be obtained with strawberry while it's $100 \%$ for squash by applying equation (1). Also, based on the database of the Tunisian Ministry of Agriculture, Hydraulic Resources and Fisheries, the amount of rainfall recorded is only $47 \mathrm{~mm}$ during all the dry and hot period (June 2019 - September 2019). At the beginning of the third year, strawberry-pepper association is removed, other less sensitive crops to salinity were grown (cabbage, potato, squash etc ...). At the end of the third year, (EC) was only $2.1 \mathrm{dS} / \mathrm{m}$ in August 2018 under squash (Table 2).

With respective average net irrigation water requirements of $3,600 \mathrm{~m}^{3} / \mathrm{ha} ; 6,000 \mathrm{~m}^{3} / \mathrm{ha} ; 1,345 \mathrm{~m}^{3} / \mathrm{ha} ; 7,174 \mathrm{~m}^{3} / \mathrm{ha}$ respectively for strawberries, pepper, potato and squash and with surface water's salinity of $1.5 \mathrm{dS} / \mathrm{m}$, the quantities of salts brought calculated by using equation (2) were $9,600 \mathrm{~kg} / \mathrm{ha}(=3,600 \mathrm{~kg} / \mathrm{ha}+6,000 \mathrm{~kg} / \mathrm{ha})$ under strawberry-pepper and 8519 
$\mathrm{kg} / \mathrm{ha}(=1345+7174)$ under potato-squash, the same amounts. Even if the quantities of salts added are almost identical for the three years, the crops grown during the third year are resistant to salinity; cabbage is poorly irrigated (or not). For squash, even with a (EC) of $5 \mathrm{dS} / \mathrm{m}$, yield reduction is negligible. Considering the average (EC) between these measured at the beginning and end of each season (line 4, Table 1) and using equation (1), relative yield (Yr) drops from $80 \%$ to $47 \%$ for the strawberry and from $90 \%$ to $76 \%$ for pepper between the first and the second year; this is a significant drop in yields, especially for strawberry. Indeed, the yields really observed in the field during the second year are low compared to the first year. A reduction yield of $50 \%$ and $40 \%$ was observed respectively for tomato and for pepper for a water salinity slightly exceeding $3 \mathrm{dS} / \mathrm{m}$, (CRUESI 1970). For fodder sorghum, watermelons and beans, irrigation water with a salinity of $5 \mathrm{dS} / \mathrm{m}$ leads to a yield reduction of $30 \%$ (Van Hoorn et al. 1968). Irrigation water productivity ( $\mathrm{kg}$ of agricultural product / $\mathrm{m}^{3}$ of irrigation water), decreases from 80 to $47 \%$ and from 90 to $76 \%$ respectively for strawberry and pepper between the first and the second year.

With (EC) of $1.95 \mathrm{dS} / \mathrm{m}$ at the end of the third year, transplanted strawberry yield reduction will be of $30 \%$ but the autumn rains will contribute to the desalination of the soil. Farmers over-irrigate if they see that the rains are poor; during sept1999April 2000 and Sept 2017-April 2018, the fresh surface water amounts used by farmers were respectively 483,957 and $303,121 \mathrm{~m}^{3}$ while average crops water requirement was only $137,595 \mathrm{~m}^{3}$.

During the second year, costs production for strawberry and pepper are low (about 50\% compared to the cost of a new facility); costs of tillage, seeds, transplanting were not considered; crops were kept during two years.

For the first and the second year, the net revenues were high (7,770 and 5,482 US $\$ /$ ha respectively) compared to the third year (2,534 US \$/ha), (last line, Table 2). It is for this reason that the strawberry-pepper combination is very coveted. Water cost is low by comparison to production cost (only $3 \%$ for strawberry).

Table 2. Measured (EC) and net revenue within the irrigated area of Diyar-Al-Hujjej during September 2017-August 2020 when only fresh surface water is available for different crops 


\begin{tabular}{|c|c|c|c|c|c|c|}
\hline \multirow{3}{*}{$\begin{array}{l}\text { Year } \\
\text { Cropping season }\end{array}$} & \multirow{2}{*}{\multicolumn{2}{|c|}{$\begin{array}{l}\text { First year } \\
\text { Sept } 2017 \text { - August } 2018\end{array}$}} & \multirow{2}{*}{\multicolumn{2}{|c|}{$\begin{array}{l}\text { Second year } \\
\text { Sept } 2018 \text { - August } 2019\end{array}$}} & \multirow{2}{*}{\multicolumn{2}{|c|}{$\begin{array}{l}\text { Third year } \\
\text { Sept } 2019 \text { - August } \\
2020\end{array}$}} \\
\hline & & & & & & \\
\hline & Sept 2016 & June2017 & Sept 2017 & June2017 & Sept2016 & June2017- \\
\hline & $\overline{\text { May2017 }}$ & August2017 & $\begin{array}{l}- \text { May } \\
2018\end{array}$ & August2017 & $\overline{\text { May2017 }}$ & August2017 \\
\hline crops & Strawberry & Pepper & Strawberry & pepper & Potato & Squash \\
\hline $\begin{array}{l}\text { Measured (EC) under crops } \\
\text { (dS/m) }\end{array}$ & 1.6 & 2.2 & 2.6 & 3.2 & 1.8 & 2.1 \\
\hline $\begin{array}{l}\text { Average (EC) during crops } \\
\text { season }(\mathrm{dS} / \mathrm{m})\end{array}$ & 1.9 & & 2.9 & & 1.95 & \\
\hline $\begin{array}{l}\text { Average (EC) during all crops } \\
\text { cycle (dS/m) }\end{array}$ & 2.25 & & & & & \\
\hline Net water requirements $\left(\mathrm{m}^{3} / \mathrm{ha}\right)$ & 3,600 & 6,000 & 3,600 & 6,000 & 1,345 & 7,174 \\
\hline Surface water cost (US \$/ha) & 180 & 300 & 180 & 300 & 67 & 358 \\
\hline Production cost (US \$/ha) & 6,000 & 700 & 3,000 & 350 & 1767 & 700 \\
\hline Crops yield & 55 & 18 & 55 & 18 & 22 & 25 \\
\hline Relative yield (\%) & 80 & 90 & 47 & 76 & 99 & 100 \\
\hline Agricultural production (kg/ha) & 44 & 16 & 26 & 14 & 22 & 25 \\
\hline Selling price & 0.300 & 0.108 & 0.300 & 0.108 & 0.133 & 0.1 \\
\hline Value of agricultural production & 13,200 & 1,750 & 7,800 & 1,512 & 2,926 & 2,500 \\
\hline Net revenue & 7,020 & 0,750 & 4,620 & 0,862 & 1,092 & 1,442 \\
\hline Annual net revenue & 7,770 & & & 5,482 & 2,534 & \\
\hline
\end{tabular}

\section{Farmers using only saline aquifer water}

These farmers do not have access to surface water. They are located outside the irrigated area or they have not paid their irrigation water bill; agriculture is not their main activity. They have very small irrigated areas, coming from the heritage. They grow rainfed crops throughout rainy period (September-April). Thus, the soil observes desalination throughout this rainy period, which allows them to cultivate mainly tomato intended for processing and which are grown early between February and June to make the most of the rain while normal tomato is grown between May and August (dry season). The main Tunisian's tomato and pepper processing factories are located in this region and in neighboring areas.

Tomato has small shape and it's unmarketable and it's intended mainly for processing. Selling price is fixed in agreement with factories and it is lower than the selling price of tomato intended for fresh consumption but they have a guarantee for the sale of their production and waste is insignificant. Factories advance all operating costs (price of seeds, fertilizers, phytosanitary products). Pepper is not grown (no surface water); pepper pod is very small. (EC) measured during the rainy season under rainfed crops and fallow are less than $2 \mathrm{dS} / \mathrm{m}$ while under tomato grown during the dry season, (EC) reached $5.37 \mathrm{dS} / \mathrm{m}$ even at the end of the first year (line 4, Table 3); keeping the soil without irrigation during the rainy season or the second year allowed a notable reduction in salinity (Fig. 2, red curve), it's a light soil and crust is present at $20 \mathrm{~cm}$ sometimes. Average Measured (EC) of Diyar-Al-Hujjej's aquifer was $6.6 \mathrm{dS} / \mathrm{m}$, (Mekni 2017). Tomato irrigation water requirements are $6,467 \mathrm{~m}^{3} / \mathrm{ha}$. The amounts of salts brought are $13,658 \mathrm{Kg} / \mathrm{ha}\left(6.6 \mathrm{dS} / \mathrm{m}\right.$ * $\left.0.64 *(6,467 / 2) \mathrm{m}^{3} / \mathrm{ha}\right)$ 
under tomato assuming that only half of the water requirements are supplied in the form of salt water ( $50 \%$ of the water needs are met by rain) while the amount of the salts supplied is only $9,600 \mathrm{~kg} / \mathrm{ha}$ for a whole year of irrigation under the strawberry-pepper combination when only surface water has been used. If all tomato water requirements were satisfied by saline water when tomato was grown during the dry season, the amount of salts brought was $27,317 \mathrm{~kg} / \mathrm{ha}$; which explains the farmers' choice for industrial tomatoes, the water requirements of which are largely satisfied by the rain. The areas intended for tomato growth fell from 450 ha to less than 100 ha between 2000 and 2019. Some farmers without access to surface water and observing low yields abandon their farms for one or two years to witness a desalinization of soil profiles under the effect of the rain; it's the case of all farmers located near the sea. In Gambia, faster germinating varieties of rice and peanuts have been developed to mature in a shorter rainy season and avoid the need for saltwater pumping as part of a challenge of adaptation to climate change (Yanl 2011). Pinckson et al.(2020) indicated that it's necessary to develop new cereal crop varieties and suggest that the prices of agricultural products must be subsidize to improve cereal varieties production under climate change threat.

Table 3. Measured (EC) and net revenue within the irrigated area of Diyar-Al-Hujjej during September 2017-August 2020 when only saline water is available for different crops 


\begin{tabular}{|c|c|c|c|c|c|c|c|c|}
\hline Years & \multicolumn{3}{|l|}{ First year } & \multicolumn{3}{|c|}{ Second year } & \multicolumn{2}{|l|}{ Third year } \\
\hline Copping season & \multicolumn{3}{|c|}{ Sept 2017 - August 2018} & \multicolumn{3}{|c|}{ Sept 2018 - August 2019} & \multicolumn{2}{|c|}{$\begin{array}{l}\text { Sept } 2019- \\
\text { August } 2020\end{array}$} \\
\hline Crops & $\begin{array}{l}\text { Rainfed } \\
\text { barly }\end{array}$ & $\begin{array}{l}\text { Tomato } \\
\text { intended for } \\
\text { processing }\end{array}$ & Fallow & $\begin{array}{l}\text { Rainfed } \\
\text { barly }\end{array}$ & $\begin{array}{l}\text { Tomato } \\
\text { intended for } \\
\text { processing }\end{array}$ & Fallow & $\begin{array}{l}\text { Rainfed } \\
\text { wheat }\end{array}$ & Fallow \\
\hline $\begin{array}{l}\text { Measuerd(EC) } \\
(\mathrm{dS} / \mathrm{m})\end{array}$ & 1.26 & 5.37 & 4.27 & 1.59 & 5.2 & 4.3 & 1.63 & 1.89 \\
\hline $\begin{array}{l}\text { Anual average } \\
\text { (EC) }(\mathrm{dS} / \mathrm{m})\end{array}$ & 3.63 & & & 3.7 & & & 1.76 & \\
\hline $\begin{array}{l}\text { (EC) for a } \\
\text { complete cycle: } \\
\text { Sept 2017-August } \\
2020\end{array}$ & 3.03 & & & & & & & \\
\hline $\begin{array}{l}\text { Net water } \\
\text { requirements }\end{array}$ & - & 6,467 & - & - & 6,467 & - & - & - \\
\hline Saline water cost & - & 129 & - & - & 129 & - & - & - \\
\hline $\begin{array}{l}\text { Crops production } \\
\text { cost }\end{array}$ & negligible & 1,808 & - & negligible & 1,808 & - & negligible & - \\
\hline Crops yield & negligible & 75 & - & negligible & 75 & - & negligible & - \\
\hline Relative yield (\%) & - & 92 & - & - & 91 & - & - & - \\
\hline $\begin{array}{l}\text { Agricultural } \\
\text { production } \\
\text { (ton/ha) }\end{array}$ & negligible & 69 & - & negligible & 68 & - & negligible & - \\
\hline Selling prices & - & $\begin{array}{l}0.0045 \\
(=0.75 * 0.06)\end{array}$ & & - & $\begin{array}{l}0.045 \\
(=0.75 * 0.06)\end{array}$ & & - & - \\
\hline $\begin{array}{l}\text { Value of } \\
\text { agricultural } \\
\text { production }\end{array}$ & - & 3,105 & & & 3,060 & & & - \\
\hline Net revenue & - & 1,168 & & - & 1,123 & - & - & - \\
\hline $\begin{array}{l}\text { Annual net } \\
\text { revenue }\end{array}$ & 1,168 & & & 1,123 & & & negligible & \\
\hline
\end{tabular}

Annual net revenue was very low (about 1,000 US\$/ha) (last line, Table 3) while it reached more than 7,000 US\$/ha when only surface water was used (last line, Table 2). Average annual returns simulated showed that fallow-wheat rotation was the most beneficial choice, compared to pearl millet-based sequences and pearl millet-wheat rotations (Kaur et al. 2007). Ahmed et al. (2019) indicated that Fallow increases water stored for the next year and found that planting lucerne in rotation 
with canola, wheat and triticale crops used more water, as did native vegetation. But here it's clear that in the irrigated areas, rainfed crops and fallow decrease soil salinity also because of no salt water supply.

\section{Farmers having access to 2 water sources (surface and saline waters)}

All farmers have in addition access to groundwater through private wells; reinforced concrete tanks or ground tanks for water blending are available also. Farmers prefer using surface water but a blending is done for salt-tolerant crops if surface water amounts are insufficient. They constitute the majority of farmers.

\subsection{Case of farmers having a fair volume of surface water}

These farmers are often owners and no tenant is interested in farms that do not contain surface water in large quantities. The strawberry-pepper combination is absent since surface water is present in small quantities. Water blending is done by injection of fresh water in wells which leads to an additional pumping cost. Unlike farmers who only have saline aquifer water who practice only rainfed crops during the rainy period, these farmers practice irrigated crops resistant to salinity during this same period. Three crops rotation are encountered:

- rainfed wheat or barley- tomato or pepper

- beans used as a green manure-potato- tomato or pepper

- cabbage-potato-squash-fallow

The crops grown till April are rainfed crops or irrigated by blended water and rain contributes to their water needs and to salt leaching.

In general, an increase in salinity is observed during the dry season following irrigation with blended water and/or groundwater; subsequently, during the rainy season, desalination took place. During the rainy periods (Sep 2017-Ap 2018 and Sep 2018-Ap 2019), (EC) varied between 1.26 and $2.5 \mathrm{dS} / \mathrm{m}$ under rainfed beans, cabbage and irrigated potato for the three years (line 4, Table 4). Subsequently, (EC) increased and reached even $5.36 \mathrm{dS} / \mathrm{m}$ in May 2017-August 2018, (line 4, Table 4); the field yield observed is low. Bani and al. (2020) found an (EC) of 3.8 and $5.5 \mathrm{dS} / \mathrm{m}$ under pepper irrigated with blended water. Saidi et al. (2010) reported that an increase of salt salinity from 2 to $8 \mathrm{dS} / \mathrm{m}$ was observed under tomato between the beginning (first May) and the end (August) of the dry irrigation season. Salt accumulation occurs mainly throughout the irrigation season. In the second year, the (EC) measured are the same (line 4, Table 4).

Table 4. Measured (EC) within the irrigated area of Diyar-Al-Hujjej during September 2017-August 2019 when surface water is available on little amounts for different crops 


\begin{tabular}{|c|c|c|c|c|c|c|c|c|}
\hline \multicolumn{2}{|c|}{ Cropping year } & \multicolumn{4}{|c|}{ September 2017- August 2018} & \multicolumn{3}{|c|}{ September 2018- August 2019} \\
\hline \multirow{2}{*}{$\begin{array}{l}\text { Crops } \\
\text { rotation } \\
\text { number }\end{array}$} & Crops season & \multicolumn{2}{|l|}{$\begin{array}{l}\text { Sep 2017- } \\
\text { Apr } 2018\end{array}$} & \multicolumn{2}{|c|}{$\begin{array}{l}\text { May - August } \\
2018\end{array}$} & $\begin{array}{l}\text { Sept } 2018 \text { - } \\
\text { Apr } 2019\end{array}$ & \multicolumn{2}{|c|}{$\begin{array}{l}\text { May - August } \\
2019\end{array}$} \\
\hline & Crops & Rainfed wheat & & Tomato & pepper & $\begin{array}{l}\text { Rainfed } \\
\text { wheat }\end{array}$ & Tomato & pepper \\
\hline \multirow{3}{*}{$\begin{array}{l}\text { First } \\
\text { crops } \\
\text { rotation }\end{array}$} & $\begin{array}{l}\text { Measuerd (EC) } \\
(\mathrm{dS} / \mathrm{m})\end{array}$ & 1.26 & & 5.36 & 4.27 & 1.68 & 5.2 & 4.3 \\
\hline & $\begin{array}{l}\text { Anual average } \\
(\mathrm{EC})(\mathrm{dS} / \mathrm{m})\end{array}$ & \multicolumn{2}{|l|}{3.6} & & & \multicolumn{3}{|l|}{3.7} \\
\hline & $\begin{array}{l}\text { (EC) for a } \\
\text { complete cycle: } \\
\text { Sep 2017- } \\
\text { August } 2020\end{array}$ & \multicolumn{2}{|l|}{3.65} & & & & & \\
\hline \multirow{5}{*}{$\begin{array}{l}\text { Second } \\
\text { crops } \\
\text { rotation }\end{array}$} & Crops season & $\begin{array}{l}\text { Spt } 2017-\text { early } \\
\text { January } 2018\end{array}$ & $\begin{array}{l}\text { January } \\
-\quad \text { April } \\
2018\end{array}$ & \multicolumn{2}{|c|}{$\begin{array}{l}\text { May - August } \\
2018\end{array}$} & $\begin{array}{l}\text { Sept 2018- } \\
\text { April } 2019\end{array}$ & \multicolumn{2}{|c|}{$\begin{array}{l}\text { May - August } \\
2019\end{array}$} \\
\hline & Crops & $\begin{array}{l}\text { Rainfed bean ( } \\
\text { as a green } \\
\text { mannure) (not } \\
\text { irrigated) }\end{array}$ & Potato & Tomato & Pepper & $\begin{array}{l}\text { Rainfed } \\
\text { barly }\end{array}$ & Tomato & Pepper \\
\hline & $\begin{array}{l}\text { Measuerd (EC) } \\
(\mathrm{dS} / \mathrm{m})\end{array}$ & 1.47 & 2.2 & 4.6 & 4.9 & 2.3 & 4.4 & 5.1 \\
\hline & $\begin{array}{l}\text { Anual average } \\
(\mathrm{EC})(\mathrm{dS} / \mathrm{m})\end{array}$ & \multicolumn{4}{|l|}{3.3} & \multicolumn{3}{|l|}{3.9} \\
\hline & $\begin{array}{l}\text { (EC) for a } \\
\text { complete cycle: } \\
\text { Sep 2017-- } \\
\text { august } 2019\end{array}$ & \multicolumn{2}{|l|}{3.6} & & & & & \\
\hline \multirow[b]{4}{*}{$\begin{array}{l}\text { Third } \\
\text { crops } \\
\text { rotation }\end{array}$} & Crops season & $\begin{array}{l}\text { Sptember 2017- } \\
\text { early January } \\
2018\end{array}$ & $\begin{array}{l}\text { January } \\
-\quad \text { April } \\
2018\end{array}$ & \multicolumn{2}{|c|}{$\begin{array}{l}\text { May - August } \\
2018\end{array}$} & $\begin{array}{l}\text { September } \\
2018-\text { April } \\
2019\end{array}$ & \multicolumn{2}{|c|}{$\begin{array}{l}\text { May - August } \\
2019\end{array}$} \\
\hline & Crops & $\begin{array}{l}\text { Rainfed cabbage } \\
\text { (not irrigated) }\end{array}$ & Potato & Squash & Fallow & Fallow & Tomato & Pepper \\
\hline & $\begin{array}{l}\text { Measuerd (EC) } \\
(\mathrm{dS} / \mathrm{m})\end{array}$ & 2 & 2.5 & 4.42 & 4.43 & 2 & 5.0 & 5.35 \\
\hline & $\begin{array}{l}\text { Anual average } \\
(\mathrm{EC})(\mathrm{dS} / \mathrm{m})\end{array}$ & 3.34 & & & & 4.16 & & \\
\hline
\end{tabular}


(EC) for a

complete cycle:

Sep 2017-

august 2019

Average measured (EC) are the same in the two cases, when only saline aquifer water was present and irrigation is done only during the dry season (Table 3) and when surface water is available on little amounts but irrigation is done during the rainy and the dry seasons (Table 4). In this last case, farmers' net revenue is better; they grow irrigated crops during the rainy season in addition. Simultaneous use of surface water and aquifer water is the most effective way to improve water use efficiency (reducing surface water diversions by 52\%) and the depth of the underground water table increased to $79 \mathrm{~cm}$ ( Weifeng et al., 2016).

By using equation (3), the net revenues were $826 ; 1,549$ and 1,386 US $\$ / \mathrm{m}^{3}$ respectively for potato, squash and tomato. For pepper the net revenue is negligible and it is rarely grown except in areas far from the sea; a reduced farmers' net income compared to those who grow strawberries when net revenue reached 7,770 US $\$ /$ ha.

The amounts of salt added were 15,$600 ; 1,345 ; 18,652$ and 16,814 $\mathrm{kg}$ / ha respectively for pepper, potato, squash and tomato, very large quantities, except for the potato cultivated during the rainy season and for which a large part of the water needs is satisfied by rain. Ignoring salinity results in a $29 \%$ reduction in agricultural profits and an average deadweight loss of US $\$ 1,200$ per year per hectare (Yehuda et al., 2020).

\subsection{Case of farmers having medium amounts of surface water.}

The strawberry-pepper combination is kept one year; subsequently, salt-tolerant crops are grown. For the strawberry-pepper combination, (EC) measured under strawberry in May 2018 is $1.6 \mathrm{dS} / \mathrm{m}$ (line 4, Table 5). Since strawberry is very sensitive to salinity, they are transplanted to soils that have been left fallow or occupied by rainfed crops the year before. Also a good part of its water need is met by rain and only good quality surface water is used for its irrigation. This is a light soil, salt leaching is also observed. For the pepper planted on the same lines as the strawberry crop but cultivated during the dry period and often irrigated with surface water or blended water, the (EC) increase and reach $3.5 \mathrm{dS} / \mathrm{m}$ in August 2018 (line 4 , Table 5 ); it does not allow keeping the strawberry - pepper association for a second year. With an (EC) of $3.5 \mathrm{dS} / \mathrm{m}$ measured at the end of the first year, the relative yield (Yr) of the strawberry calculated by using equation (1) will be under $10 \%$; farmers grow strawberry-pepper on other different lands due to its profitability.

Under the less salt-sensitive crops grown in the second year, the measured (EC) decreased and they were 1.15, 1.25 and 2.12 $\mathrm{dS} / \mathrm{m}$ under respectively cabbage, potato and fallow (Table 5). For these crops grown during the rainy season, only surface water is used if irrigation is necessary; rain compensates a good part of their water needs. The highest (EC) was observed under pepper grown during the dry season (penultimate line, Table 5).

Table 5. Measured (EC) and net revenue within the irrigated area of Diyar-Al-Hujjej during September 2017-August 2019 when surface water is available on medium amounts for different crops 


\begin{tabular}{|c|c|c|c|c|c|}
\hline \multirow{2}{*}{$\begin{array}{l}\text { Years } \\
\text { Crops season }\end{array}$} & \multicolumn{2}{|l|}{ First year } & \multicolumn{3}{|c|}{ Second year } \\
\hline & $\begin{array}{l}\text { Sep 2017-May } \\
2018\end{array}$ & $\begin{array}{l}\text { June -August } \\
2018\end{array}$ & $\begin{array}{l}\text { Sept-dec } \\
2018\end{array}$ & $\begin{array}{l}\text { Dec-April } \\
2019\end{array}$ & $\begin{array}{l}\text { May-August } \\
2019\end{array}$ \\
\hline Crops & Strawberry & Pepper & $\begin{array}{l}\text { Rainfed } \\
\text { cabbage }\end{array}$ & Potato & Fallow \\
\hline Measuerd (EC) (dS/m) & 1.6 & 3.5 & 1.15 & 1.25 & 2.12 \\
\hline \multicolumn{6}{|l|}{ Anual average (EC) (dS/m) } \\
\hline $\begin{array}{l}\text { (EC) for a complete cycle: Sep 2017- } \\
\text { august } 2020\end{array}$ & 2.02 & & & & \\
\hline & 3,600 & 6,000 & - & 1,345 & - \\
\hline \multicolumn{6}{|l|}{ Net water requirements } \\
\hline & 180 & 300 & - & 67 & - \\
\hline \multicolumn{6}{|l|}{ Water cost } \\
\hline \multicolumn{6}{|l|}{$\begin{array}{l}\text { Crops } \\
\text { production cost }\end{array}$} \\
\hline Crops yield & 55 & 18 & - & 22 & - \\
\hline \multicolumn{5}{|l|}{ Measuerd (EC) (dS/m) } & - \\
\hline \multicolumn{6}{|l|}{ Relative yield (\%) } \\
\hline \multicolumn{6}{|l|}{ Agricultural production (ton/ha) } \\
\hline \multicolumn{6}{|l|}{ Selling price } \\
\hline \multicolumn{6}{|l|}{ Value of agricultural production } \\
\hline \multicolumn{6}{|l|}{ Net revenue } \\
\hline Annual net revenue & 7,532 & & 2,926 & & \\
\hline
\end{tabular}

The net revenues were 7,532 and only 2,926 US \$/ha during the first and the second year (last line, Table 5), the profitability of the combination strawberry-pepper is clear. For farmers having only surface fresh water, the net revenues were 7,770 and 
5,482 US $\$ /$ ha respectively for the first and the second year (Table2). Salt brought under strawberry is $3,600 \mathrm{~kg} / \mathrm{ha}$ while it is $6,000 \mathrm{~kg} / \mathrm{ha}$ for pepper (three times) while the net income of strawberry is more than fourteen times that of pepper.

\subsection{Case of farmers having an important volume of surface water and large irrigated areas}

They are full time farmers and they are often large tenants of lands. They over-irrigate to leach salt as much as possible. The strawberry-pepper combination is kept often two years; there after more resistant crops are grown. (EC) measured under strawberry was only $1.53 \mathrm{dS} / \mathrm{m}$ in May 2018 (line 4, Table 6) because only surface water is used, the relative yield is about $80 \%$ calculated by using equation (1). The rains contribute to the water requirements and often salt leaching is present. $A$ little increase in (EC) (2.2 dS / m) under pepper in August 2018 was measured (line 4, Table 6), the pepper being irrigated with surface water or blended water if surface water is missing. Farmers are aware that soil salinity must remain low to be able to keep the strawberry-pepper association for another year. For these farmers, given the medium (EC) measured and as the strawberry plants are expensive and are imported (plant cost is about 0.2 USD and the need of one hectare is about 30,000 plants), this combination was kept for a second year but (EC) measured during the end of the second year was high compared to the first year (4.7 dS/m under pepper in August), (line 4, Table 6), (Fig. 2, green curve). A reduction of field yield is observed. By using equation (1), relative yield is only $40 \%$ for strawberry. Already, in recent years, if a cycle of drought is observed and in the absence of heavy rains in September, the strawberry-pepper association has been removed at the end of the first year.

Given the high salinity, crops less sensitive to salinity such as cabbage, potato, squash or rainfed crops are grown in the third year; a decrease in salinity was observed. Average annual (EC) was $2.36 \mathrm{dS} / \mathrm{m}$ for the third year while it's $4 \mathrm{dS} / \mathrm{m}$ for the second year (line 5, Table 6). These farmers are all tenants and they have large irrigated areas; they don't stop practicing the strawberry-pepper association but on other parts of their irrigated area. One of the tenants, with whom we conducted the experiments, rented a total area of 33 ha and had 12 hydrants and 5 wells. He has access even to water from a nearby little dam (Lebna), which has very good water quality.

The profitability of the combination strawberry-pepper is clear; the net revenue for the second year is low compared to the first year but it's two times more than this of the third year; the net revenues were 8,331; 4,150 US $\$ /$ ha for the first and the second year when strawberry is present while it was 2,094 US \$/ha during the third year when only other crops were grown (last line, Table 6). This advantage in income under strawberry-pepper encourages farmers to keep this combination for a second year. Some farmers rent large land just to have several surface water hydrants at their disposal and they can practice the strawberry-pepper combination annually.

Table 6. Measured (EC) and net revenue within the irrigated area of Diyar-Al-Hujjej during September 2017-August 2020 when surface water is available on important amounts under different crops 


\begin{tabular}{|c|c|c|c|c|c|c|c|}
\hline Years & First year & & Second yea & & Thirdyear & & \\
\hline Crops season & $\begin{array}{l}\text { Sep } 2017- \\
\text { May } 2018\end{array}$ & $\begin{array}{l}\text { June } \\
\text { August } \\
2018\end{array}$ & $\begin{array}{l}\text { Sep 2018- } \\
\text { May } 2019\end{array}$ & $\begin{array}{l}\text { June- } \\
\text { Aug } \\
2019\end{array}$ & $\begin{array}{l}\text { Sept - } \\
\text { Dec } 2019\end{array}$ & $\begin{array}{l}\text { Dec- } \\
\text { April } \\
2020\end{array}$ & $\begin{array}{l}\text { May- } \\
\text { August } \\
2020\end{array}$ \\
\hline Crops & Strawberry & Pepper & Strawberry & Pepper & $\begin{array}{l}\text { Rainfed } \\
\text { cabbage }\end{array}$ & Potato & Squash \\
\hline Measuerd (EC) (dS/m) & 1.53 & 2.2 & 3.31 & 4.7 & 2.47 & 2.12 & 2.5 \\
\hline Anual average (EC) (dS/m) & 1.86 & & 4 & & 2.36 & & \\
\hline \multicolumn{8}{|l|}{$\begin{array}{l}\text { (EC) for a complete cycle: Sep } \\
2017 \text { - August } 2020(\mathrm{dS} / \mathrm{m})\end{array}$} \\
\hline Net water requirements $\left(\mathrm{m}^{3} / \mathrm{ha}\right)$ & 3,600 & 6,000 & 3,600 & 6,000 & 0 & 1,345 & 7,174 \\
\hline Water cost(US \$/ha) & 180 & 300 & 180 & 300 & 0 & 67 & 359 \\
\hline Crops production cost(US \$/ha) & 6,000 & 700 & 3,000 & 350 & - & 1767 & 700 \\
\hline Crops yield (tons/ha) & 55 & 18 & 55 & 18 & - & 22 & 25 \\
\hline Relative yield (\%) & 83 & 88 & 42 & 58 & - & 85 & 100 \\
\hline Agricultural production (ton/ha) & 46 & 15.8 & 23 & 10 & - & 18.7 & 25 \\
\hline Selling price(US \$/kg) & 0.300 & 0.108 & 0.300 & 0.108 & - & 0.133 & 0.1 \\
\hline $\begin{array}{l}\text { Value of agricultural } \\
\text { production(US \$/ha/ton) }\end{array}$ & 13,800 & 1,711 & 6,900 & 1,080 & - & 2,487 & 2,500 \\
\hline $\begin{array}{l}\text { Net revenue } \\
\text { (US \$/ha) }\end{array}$ & 7,620 & 711 & 3,720 & 430 & negligible & 653 & 1,441 \\
\hline $\begin{array}{l}\text { Annual net revenue } \\
\text { (US \$/ha/year) }\end{array}$ & 8,331 & & 4,150 & & & 2,094 & \\
\hline
\end{tabular}

\section{Synthesis analysis}

Page 15/23 
When surface water is available on medium or important amounts, average (EC) for a complete cycle is less than $3 \mathrm{dS} / \mathrm{m}$ while it's more than this value when only saline water or little amounts of surface water are available (fourth column, Table 7). Measured (EC) under tomato irrigated with saline or when surface water is present on little amounts were more than 5 $\mathrm{dS} / \mathrm{m}$ (Tables 3 and 4). Even if salinities increase during the irrigation season and decrease during the rainy season; very high (EC) were measured under crops during the irrigated season and which are the cause of drop in yields. (EC) increases from 3 to more than $8 \mathrm{dS} / \mathrm{m}$ within the surface layer between the start and the end of the tomato irrigation season (Saidi et al. 2018). Salinity management is directly linked to irrigation management and scheduling. In our irrigated area, (EC) was measured on February $26^{\text {th }}, 2021$, within two irrigated plots, (i) in the first plot, crops rotation (irrigated crops, rainfed crops and fallows) were applied during 2016, 2017, 2018 and 2019 but surface water was used with a low (EC) of less than 1 dS / $\mathrm{m}$, and (ii) in a neighboring rainfed area (during all the cycle 2016-2019). (EC) varied between 1.7 and $1.9 \mathrm{dS} / \mathrm{m}$ for the first case and it's about $1.5 \mathrm{dS} / \mathrm{m}$ for the second case; not so different when salt tolerant crops were grown. Farmers need to be convinced that rational irrigation water management is important both to the welfare of farmers and the environment (Lazaridou et al. 2019). Even if (EC) measured under crops reached almost $6 \mathrm{dS} / \mathrm{m}$, we see that for total crops cycle, the (EC) was less than $4 \mathrm{dS} / \mathrm{m}$ in all cases (fourth column, Table 7); hence the interest of the introduction of crops rotation. Keeping soil under rainfed crops reduce soil salinity, besides other advantageous. Crops rotation breaks the cycle of harmful organisms affecting crops by restricting pathogens and weeds (Leteinturier et al. 2007). In our irrigated area, potato grown after a cabbage is of good quality compared to the potato grown after the strawberry-pepper combination (it has blackish spots) after the Diyar-Al-Hujjej framers and some samples were noted by ourselves. During the last five years (2016-2020) surface water transfer is negligible (Tab. 1) compared to crop water requirements $\left(2,500,000 \mathrm{~m}^{3}\right)$. The water table depth is $20.5 \mathrm{~m}$; measured surface water and groundwater (one well) (EC) were respectively 2.2 and $4.42 \mathrm{dS} / \mathrm{m}$ on $2^{\text {th }}$ December 2020. No significant change in water table depth since 2000 . On February $26^{\text {th }}, 2021,(E C)$ of surface water, blended water and wells are respectively $2.82,3.08$ and $4.63 \mathrm{dS} / \mathrm{m}$.

Growing strawberry-pepper on second year leads to high salinity (4 dS/m, (penultimate line, third column, Table 7) even if surface water is available on important amounts but farmers opt for this solution saw the net income achieved when strawberry is grown (last column, Table 7 ). Net revenue obtained with $50 \%$ of strawberry yield is higher than any other net revenue obtained with other crops even under low salinity. When only saline water or surface water is available on little amounts, not only net revenue is less than 1,850 US \$/ha but also quantities of salt brought were high, reaching 18,102 $\mathrm{kg} / \mathrm{ha} /$ year (columns 5 and 6, Table 7). In San Joaquin Valley, only 2,000 kg salt/ha is added to irrigate summer crops (cotton, alfalfa) if a high quality irrigation water is used (Kenneth et al. 1986). Extension services should recommend stopping this type of irrigations; over-exploitation of the aquifer leds to sea intrusion.

The net annual revenue is generally greater than 5,000 US $\$ /$ ha/year when strawberry is present while it is less than 2,000 US $\$ /$ ha/year when this crop is absent (last column, Table 7). For this crop, a large-scale processing industry must be set up to absorb the over-production of a rapidly deteriorating crop.

Table 7.Measured (EC), salt brought and net revenue within the irrigated area of Diyar-Al-Hujjej during September 2017August 2020 under different crops rotation and for different water sources 


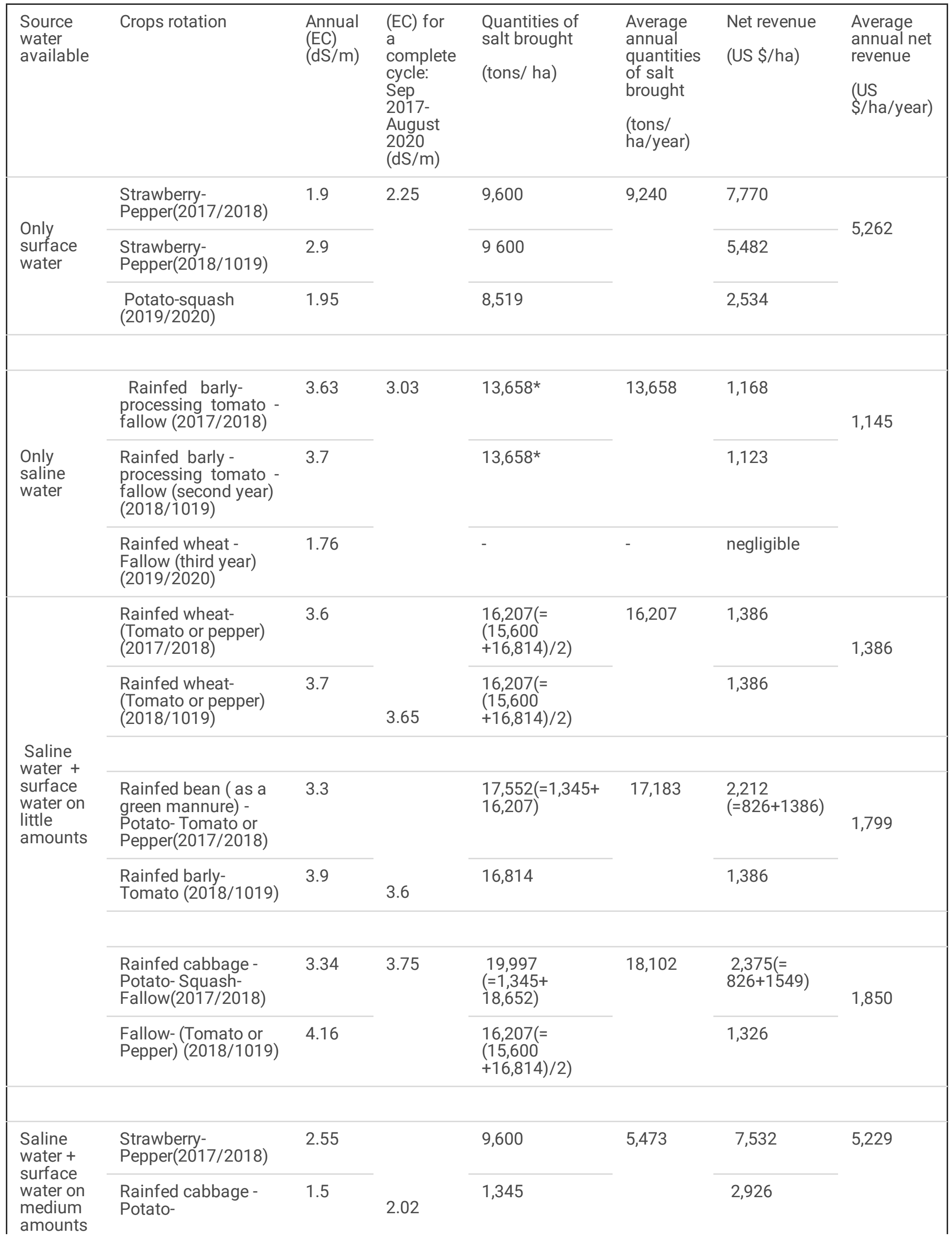


Fallow(2018/1019)

\begin{tabular}{|c|c|c|c|c|c|c|}
\hline \multirow{3}{*}{$\begin{array}{l}\text { Saline } \\
\text { water + } \\
\text { surface } \\
\text { water on } \\
\text { important } \\
\text { amounts }\end{array}$} & $\begin{array}{l}\text { Strawberry- Pepper } \\
(2017 / 2018)\end{array}$ & 1.86 & & 9,600 & \multirow[t]{3}{*}{9,240} & 8,331 \\
\hline & $\begin{array}{l}\text { Strawberry- Pepper } \\
(2018 / 1019)\end{array}$ & 4 & \multirow[b]{2}{*}{2.74} & 9,600 & & 4,150 \\
\hline & $\begin{array}{l}\text { Rainfed cabbage - } \\
\text { Potato- } \\
\text { Squash(2019/2020) }\end{array}$ & 2.36 & & 8,519 & & 2,094 \\
\hline
\end{tabular}

${ }^{*}$ ) for processing tomato grown on early season, only half of these water requirements are assumed to be supplied by groundwater, the other half is supplied by rain.

All the dry season crops must be discarded and replaced by crops whose water needs are partly met by rain such as artichoke, a crop very tolerant to salinity and highly sought after for export. Also, the sensitivity of crops to salinity depends on the vegetative stage; the effect of irrigation with saline water in development stages is low (Ashraf and Harris 2004). Tomato and pepper under green house can constitute another alternative especially as these crops are profitable even if desalination is introduced and this is a region where the greenhouse activity already exists. Other irrigation techniques must be introduced. Subsurface drip irrigation (SDI) reduce evaporation losses during the pre-plant and early-season periods and improve water storage efficiency and crop yield even at low irrigation capacity (Bordovsky 2020). A significant impact in conserving groundwater can be obtained when improved irrigation at a farm level is applied (Ajaz et al. 2020). Additional effort is required from extension services; the profitability and productivity of Boro rice, as well as water productivity, were comparatively higher for focal farmers compared to control farmers (Uddin et al. 2020). The social benefits must be taken in consideration; Ryu et al. (2019) found that when only economic costs and benefits were considered, the benefit-cost ratio for the public system (0.02) was smaller than that for the private system (0.264) while, the results of the two alternatives changed when social benefits were considered. New technologies can also improve water productivity (Mansour and al. 2016).

\section{Conclusion}

This perimeter is still managed with old reflexes when only salt water was present; low-income crops (squash, tomato) tolerant to salinity are still grown even though they are the source of strong soil salinization, aquifer over-exploitation and sea intrusion. Choice of crops must be reviewed.

Crops grown during the rainy season (strawberry, potato) and for which a good part of their water needs are met by rain have led to a high net income and a low amounts of brought salt (about 7,000 US \$/ha and 3,600 kg/ha for strawberry) compared to the crops grown during the dry season when salt brought amounts were more than $13,000 \mathrm{~kg} / \mathrm{ha}$ and net revenue was less than 2,000 US \$/ha. In the presence of salty water, irrigation management is the key of success of any irrigation project.

The practice of rainfed crops and fallow during the rainy season allowed a salinity reduction within the soil profiles. The salinity measured under irrigated tomato is greater than $5 \mathrm{dS} / \mathrm{m}$ while that measured under rainfed wheat or barley is less than $2 \mathrm{dS} / \mathrm{m}$ in the same farms.

The economics of natural resources must answer these complex questions, what is better if surface water is missing? (i) growing crops that coincide with the rainy season and/or faster germinating varieties but often with low net revenue (as processing tomato), (ii) accepting a low net income and protect the soil against salinity by growing only rainfed crops and stop sea intrusion but we must think about compensating these farmers, and (iii) are present crops rotations maintain or degrade soils proprieties; an interdisciplinary research is needed?

Page $18 / 23$ 
However, other durable solutions need to be examined on a larger scale, can desalinated water be an alternative if a water social price subsidized by the state will be applied. The case of this perimeter can constitute a roadmap for several other perimeters suffering from lack of water and excessive salinity.

\section{Declarations}

\section{Ethics approval and consent to participate}

Ethics clearance was granted by Research and Innovation, Office of the Director, University of Venda, Project No:

SMNS/19/ZOO/02/0307.

\section{Consent for publication}

Not applicable

\section{Availability of data and materials}

The datasets used and/or analysed during our study are available from the corresponding author on reasonable request.

\section{Competing interests}

The authors declare that they have no competing interests.

\section{Funding}

Funding covering the costs of equipment, transport and sample analysis was provided by the SARCHI Chair in Biodiversity and Change in the Vhembe Biosphere Reserve, University of Venda.

\section{Authors' contributions}

DCT conducted the fieldwork and wrote the manuscript. PJT supervised the project, IEJB co-supervised the project. Both PJT and IEJB reviewed and provided invaluable feedback on the manuscript. All authors reviewed the manuscript.

\section{Acknowledgements}

We acknowledge Duncan MacFadyen and Gavin Anderson for approving the research to be conducted on the Venetia diamond mine. We thank the Venetia diamond mine environmental department who provided crucial support and logistics for the undertaking of this study for which we are exceedingly grateful. A monumental thanks to Ibart Janse van Rensburg for his invaluable assistance organising the logistics and admin for mine access for D. Cory-Toussaint and the after-hours assistance with bat capture on the mine. We acknowledge and thank Charney Anderson-Small (Central Analytical Facility, Stellenbosch University) for conducting the sample analysis. We extend our gratitude to Alexandra Howard who assisted with meticulously sorting and identifying the arthropod samples, and with the preparation of the arthropod reference slides. We acknowledge the funding provided by the SARCHI Chair in Biodiversity and Change in the Vhembe Biosphere Reserve, University of Venda.

\section{References}

Abbas Q, Nurunnabi M, Alfakhri Y (2020) The role of fixed capital formation, renewable and non-renewable energy in economic growth and carbon emission: a case study of Belt and Road Initiative project. Environ Sci Pollut Res 27, 4547645486. https://doi.org/10.1007/s11356-020-10413-y

Ajaz A, Andales D, Rudnick et José L., Chavez (2020) Special issue: improving irrigation management across the Ogallala aquifer, USA, Irrigation Science, volume38, 481-483. 
Ahmed K, Ghulam Qadir G, Nawaz MQ, Sarfraz M, Rizwan M., Muhammad Anwar Zak M A, Hussain S, (2019) Feasibility of different crop rotations for cultivation in salt affected soils, Acta Agriculturae Slovenica, Vol 114, № 1

Allen RG, Pereira LS, Raes D, Smith M, (1998) Crop evapotranspiration, Guidelines for Computing Crop Water Requirements, FAO, Rome 1998, FAO Irrigation and Drainage Paper 56.

Arafat AA, Abdulrasoul A, (2019), Simulated tomato yield, soil moisture, and salinity using fresh and saline water: experimental and modeling study using the SALTMED model, Irrigation Science doi:10.1007/s00271-019-00639-1.

Aragüés R, Urdanoz V, Çetin M, Kirda C, Daghari H, Ltifi W, Lahlou M, and Douaik A, (2011) "Soil salinity related to physical soil characteristics and irrigation management in four Mediterranean irrigation districts". Agricultural Water Management, 98 (6), 959-966.

Ashraf M, Harris PJC., (2004) Potential biochemical indicators of salinity tolerance in plants. Plant Sci 166:316.https://doi.org/10.1016/j.plantsci.2003.10.024.

Ayers RS, \& Westcot DW(1976) Water Quality for Agriculture, FAO Irrigation and Drainage. Paper No. 29, Rome. 97 pp.Google Scholar.

Bani A, Daghari I, Hatira A, Chaabane A., Daghari H, (2020) Sustainable management of a cropping system under salt stress conditions (Korba, Cap-Bon, Tunisia), Environmental Science and Pollution Research 07/2020; 24(6).

Bordovsky J P (2020) Pre-plant and early-season cotton irrigation timing with deficit amounts using subsurface drip (SDI) systems in the Texas High Plains, USA Irrigation Science,volume38, 485-499.

Chekirbane A, Tsujimura M, Kawachi A (2014) Use of a time-domain electromagnetic method with geochemical tracers to explore the salinity anomalies in a small coastal aquifer in north-eastern Tunisia, Hydrogeol J 22:

1777.https://doi.org/10.1007/s10040-014-1180-7.

CRUESI (1970) Research and training on irrigation with saline water. Technical Report, CRUESI Tunis/ UNESCO

Daghari I, Bani A, Bousnina H, Chaabane A (2020a) on-farm water and salt management under a strawberry-pepper combination in the Korba area. Irrig. and Drain., 69: 441-447 https://doi.org/10.1002/ird.2422.

Daghari I, El Zarroug MR, Muanda C , Shanak N (2020b) Best irrigation scheduling way with saline water and desalinated water: Field experiments. La Houille Blanche 2020, 4, 72-74

El-Juhany L, (2010) Degradation of date palm trees and date production in Arab countries: causes and potential rehabilitation, Aust. J. Basic Appl. Sci., 2010, 4 (8), 3998-4010.

GDA (Diyar-al- hujjej farmer's association (izdihar), 2021, technical report

Hamrouni H, Daghari H (2010) Managing natural resources through implementation of sustainable policies. Qualiwater project publications.

Kaur R, Malik R, Paul M (2007), Long-term effects of various crop rotations for managing salt-affected soils through a field scale decision support system - a case study, soil use and management, British society of soil science (free access) ,https://doi.org/10.1111/j. 1475-2743.2006.00055.x

Kenneth G, Cassman D, William R, (1986), A cropping systems approach to salinity management in California, American Journal of Alternative Agriculture, Vol. 1, No. 3 (Summer 1986), pp. 115-121 (7 pages), Cambridge University

Press,https://www.jstor.org/stable/44506943.

Page 20/23 
Lahlou M, Badraoui M, Soudi B, (2000), Modélisation de l'évolution de la salinité et de l'alcalinité dans les sols irrigués, IAV, Maroc, CCSD, cirad-00180360, version 1, 135-151

Leteinturier B, Tychon B, Oger R (2007)Agronomic and agro-environnemental diagnosis of cultural successions in Wallonia « (Belgium)», BASE [on ligne], 2007, Numéro 1, Volume 11.

Lazaridou D, Michailidis A, Trigkas M (2019) Socio-economic factors influencing farmers' willingness to undertake environmental responsibility. Environ Sci Pollut Res 26, 14732-14741. https://doi.org/10.1007/s11356-018-2463-7

Maas EV, Hoffman GJ, (1977) Crop salt tolerance - current assessment. J. Irrig. Drain. Div. 103, pp. 115-134.

Mansour H A, Abd El-Hady M, Bralts VF, Engel BA (2016) Performance automation controller 290 of drip irrigation systems using saline water for wheat yield and water productivity in Egypt. 291 J. Irrig. Drain Eng.

Mekni A (2017) Characterization of the artificial recharge of the Korba-El Mida aquifer by treated wastewater: hydrodynamic, hydrochemical and hydrological modeling approaches. PhD thesis, INAT, Tunisia.

Pickson RB, He G, Ntiamoah EB (2020) Cereal production in the presence of climate change in China. Environ Sci Pollut Res 27, 45802-45813 (2020). https://doi.org/10.1007/s11356-020-10430-x

Ryu J, Kim K., Oh, M. (2019) Why environmental and social benefits should be included in cost-benefit analysis of infrastructure?. Environ Sci Pollut Res 26, 21693-21703. https://doi.org/10.1007/s11356-019-05475-6

Saidi A, Daghari H, Hammami M, Hatira A, Hachani K (2010) Bilan d'eau et des sels dans le périmétre de Kalaat Andalous, rapport du projet QUALIWATER pp :1-5.

Söderström M (1992) Environ. Geol. Water Sci 20: 85. https://doi.org/10.1007/BF01737875

Saidi A, Hammami M, Daghari H, Ben Ali H, Boughdiri A, (2018) Irrigation Management Evaluation and Hydrosalinity Balance Within Kalaat El Andalous Irrigation District, North-East Tunisia ${ }^{\dagger}$ Irrigation and Drainage, volume 67(4). pp538-564. https://doi.org/10.1002/ird.2262

Saidi A, Daghari H, Hammami M, Hatira A, Hachani K (2010), Bilan d'eau et des sels dans le périmètre de Kalaat-Al-Andalous, rapport du projet QUALIWATER pp :1-5.

Söderström, M. Environ. Geol. Water Sci (1992) 20: 85.

Slater Y, Finkelshtain I, Reznik A, Kan I ( 2020 ) Large-Scale Desalination and the External Impact on Irrigation-Water Salinity: Economic Analysis for the Case of Israel. Water

RessourcesResearch,volume56,e2019WR025657. https://doi.org/10.1029/2019WR025657

Uddin MT, Dhar AR, Assessing the impact of water-saving technologies on Boro rice farming in Bangladesh: economic and environmental perspective. Irrig Sci 38, 199-212 (2020). https://doi.org/10.1007/s00271-019-00662-2

Van Hoorn JW, Ollat C, Combremont R, Novikoff G (1968) Irrigation with Salty Water in Tunisia. In: Boyko H. (eds) Saline Irrigation for Agriculture and Forestry. World Academy of Art and Science, vol 4. Springer, Dordrecht

Yanl, A. (30/01/2011), Le défi de l'adaptation aux changements climatiques, le cas de la Gambie (30/11/2011) www.sciencpresse.qc.ca.

Weifeng Yue · Xianze Liu· Tiejun Wang et Xunhong Chen (2016) : Impacts of water saving on groundwater balance in a large-scale arid irrigation district, Northwest China, irrigation science, volume 34,P297-312.

Page 21/23 


\section{Figures}

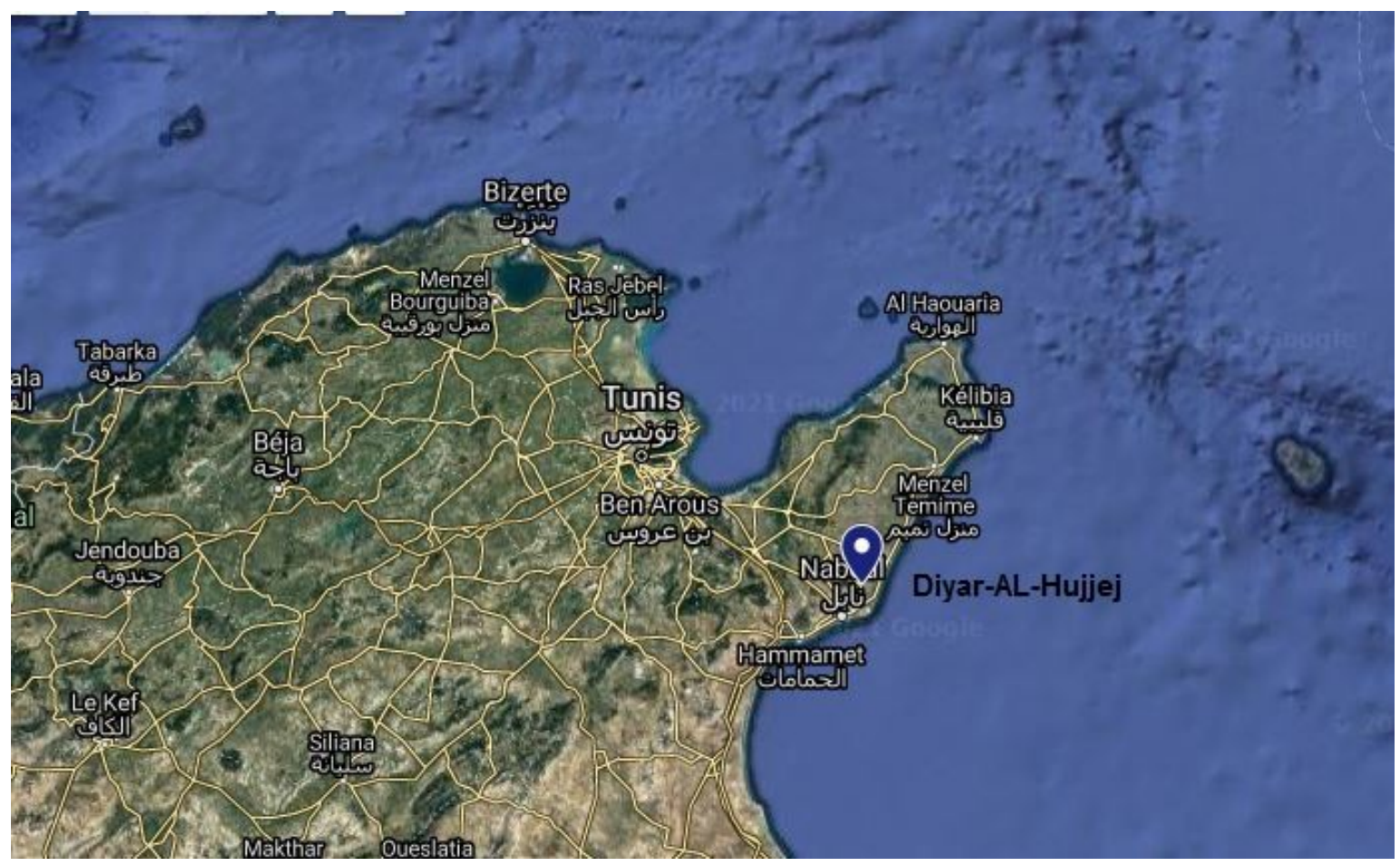

\section{Figure 1}

Geographic position of Diyar-Al-Hujjej (Tunisia) (google maps). Note: The designations employed and the presentation of the material on this map do not imply the expression of any opinion whatsoever on the part of Research Square concerning the legal status of any country, territory, city or area or of its authorities, or concerning the delimitation of its frontiers or boundaries. This map has been provided by the authors.

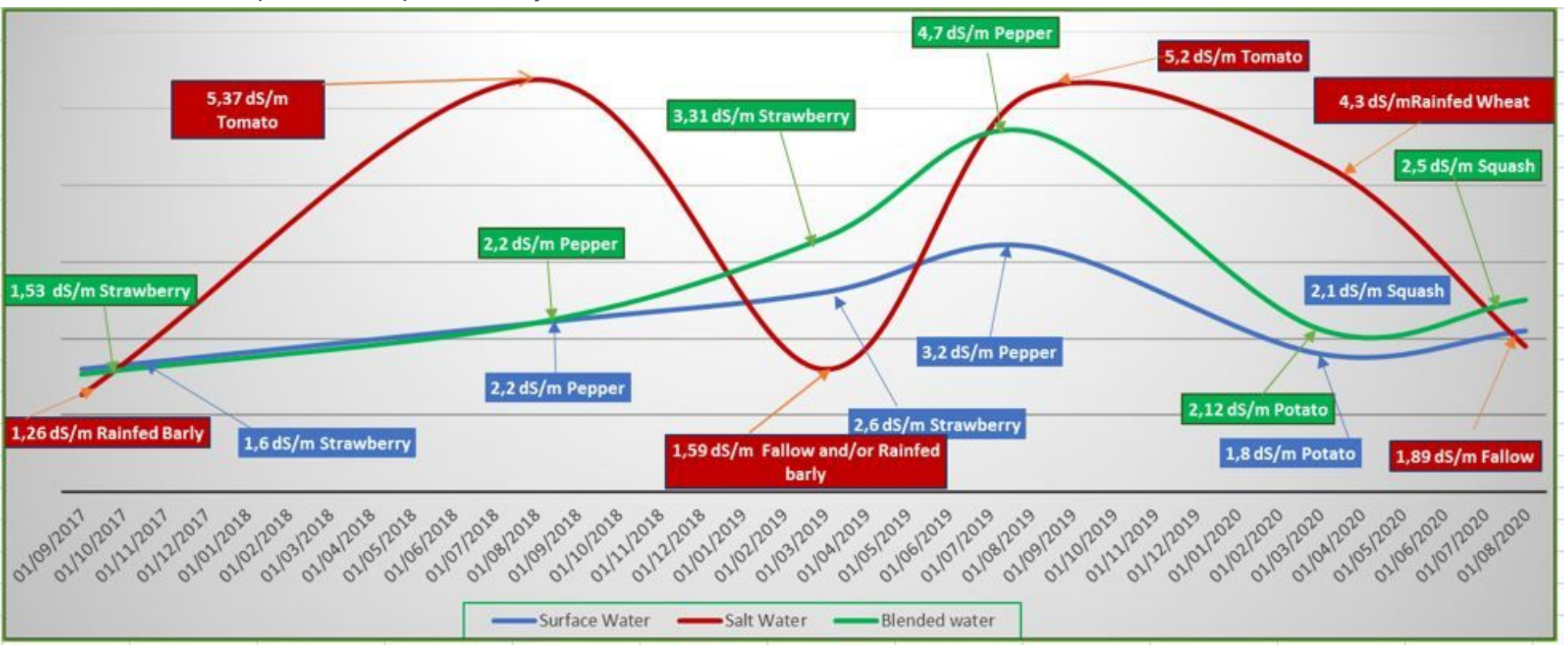

Figure 2 
Electrical conductivity (EC) in dS/m measured under irrigated, rainfed corps and fallow in Diyar-Al-Hujjej (Tunisia) during 2017-2020. 